\title{
Korelasi Antara Konsep Diri dengan Penguasaan Kompetensi Pengetahuan IPS
}

\author{
Ni Putu Wulandari ${ }^{*}$, I Wayan Sujana², I Komang Ngurah Wiyasa3
}

1 Jurusan PGSD Universitas Pendidikan Ganesha Singaraja, Indonesia

${ }^{2}$ Jurusan PGSD Universitas Pendidikan Ganesha Singaraja, Indonesia

${ }^{3}$ Jurusan PGSD Universitas Pendidikan Ganesha Singaraja, Indonesia

\begin{abstract}
Abstrak
Penelitian ini bertujuan untuk mengetahui korelasi antara konsep diri dengan penguasaan kompetensi pengetahuan IPS siswa kelas IV SD Gugus VI Pangeran Diponegoro Denpasar Barat, pada tahun pelajaran 2017/2018. Jenis penelitian ini adalah penelitian ex post facto. Populasi dari penelitian ini merupakan seluruh siswa kelas IV SD yang berada di Gugus VI Pangeran Diponegoro Denpasar Barat Tahun Pelajaran 2017/2018 yang memiliki jumlah populasi 401 siswa. Penentuan sampel menggunakan teknik proporsional random sampling dengan taraf kesalahan 5\% dan diperoleh banyak sampel dari populasi sejumlah 186 siswa. Data konsep diri diperoleh melalui kuesioner dan data penguasaan kompetensi pengetahuan IPS didapatkan melalui pencatatan dokumen yaitu nilai UAS semester I. Sebagai uji persyaratan menggunakan uji normalitas sebaran data. Setelah seluruh uji prasyarat terpenuhi, analisis statistik yang digunakan pada penelitian ini, berikutnya adalah uji hipotesis menggunakan analisis korelasi product moment. Berdasarkan hasil analisis maka diperoleh rhitung $=0,265$. Pada taraf signifikansi $5 \% n=186$, maka diperoleh rtabel $=$ 0,148. Karena rhitung=0,265 > rtabel = 0,148 maka dapat diartikan bahwa HO ditolak dan Ha diterima. Jadi dapat disimpulkan bahwa terdapat korelasi antara konsep diri dengan penguasaan kompetensi pengetahuan IPS siswa kelas IV SD Gugus VI Pangeran Diponegoro Denpasar Barat Tahun Pelajaran 2017/2018, dengan arah korelasi positif, artinya semakin tinggi konsep diri semakin meningkat penguasaan kompetensi pengetahuan IPS.
\end{abstract}

Keywords:

konsep diri, penguasaan kompetensi pengetahuan IPS.

\section{PENDAHULUAN}

Undang-undang Nomor 20 Tahun 2003 tentang system Pendidikan Nasional menyatakan bahwa "Kurikulum adalah seperangkat rencana dan peraturan mengenai tujuan, isi, dan bahan pelajaran serta cara yang digunakan sebagai pedoman penyelenggaraan kegiatan pembelajaran untuk mencapai tujuan pendidikan tertentu". Tujuan kurikulum 2013 yaitu untuk mempersiapkan manusia Indonesia agar memiliki kemampuan yang handal sebagai pribadi dan warga negara yang beriman, produktif, kreatif, inovatif, dan efektif serta mampu berkontribusi pada kehidupan bermasyarakat, berbangsa, bernegara, dan peradaban dunia. Kurikulum 2013 dikemangkan dengan landasan filosofis yang memberikan dasar bagi pengembangan seluruh potensi siswa menjadi manusia Indonesia berkualitas yang tercantum dalam tujuan pendidikan.

Kurikulum 2013 merupakan kurikulum yang baru diberlakukan di seluruh Indonesia saat ini. Kurikulum merupakan salah satu unsur yang memberikan kontribusi untuk mewujudkan proses perkembangan kualitas pendidikan di Indonesia dalam upaya meningkatkan sumber daya manusia yang handal dan memiliki potensi yang tinggi. Di pulau Bali khususnya di kota Denpasar, jenjang pendidikan yang menerapkan kurikulum 2013 secara serentak yaitu SD/MI, SMP dan SMA/K sederajat yang telah menerapkan kurikulum 2013. Kurikulum 2013 merupakan aktualisasi kurikulum dalam pembelajaran dan pembentukan karakter siswa, selain itu dikembangkan untuk menyempurnakan pola pikir siswa dalam penguatan pembelajaran aktif-mencari. Hal tersebut menuntut keaktifan dan kreatifan guru dalam pengelolaan kelas serta merancang kegiatan sesuai dengan rencana yang telah diprogramkan pada RPP (Rencana Pelaksanaan Pembelajaran)

Permendikbud nomor 22 tahun 2016 pada bagian proses pembelajaran menyatakan, proses pembelajaran pada satuan pendidikan diselenggarakan secara interaktif, inspiratif, menyenangkan, 
menantang, memotivasi siswa untuk berpartisipasi aktif, serta memberikan ruang yang cukup bagi prakarsa, kreativitas, dan kemandirian sesuai dengan bakat, minat, dan perkembangan fisik serta psikologis siswa.

Untuk itu setiap satuan pendidikan melakukan perencana pembelajaran, pelaksanaan proses pembelajaran serta penilaian proses untuk meningkatkan efisiensi dan efektivitas ketercapaian kompetensi lulusan. Dalam proses pendidikan tentunya menyangkut proses kegiatan belajar-mengajar. Susanto (2013:4) menyatakan. Belajar adalah suatu aktivitas yang dilakukan seseorang dengan sengaja dalam keadaan sadar untuk memperoleh suatu konsep, pemahaman, atau pengetahuan baru sehingga memungkinkan seseorang terjadi perubahan perilaku yang relatif tetap baik dalam berfikir, merasa, maupun dalam bertindak.

Maka berdasarkan hal tersebut belajar adalah suatu proses psikis untuk memperoleh suatu konsep, pemahaman, pengetahuan baru yang berlangsung dalam interaksi antara subjek dengan lingkungannya dan menghasilkan perubahan tingkah laku yang dilakukan secara sengaja untuk mendapatkan perubahan yang lebih baik. Berdasarkan uraian konsep belajar diatas, dapat dipahami makna hasil belajar. Tujuan dari proses belajar adalah mencapai tujuan pembelajaran yaitu mendapatkan hasil belajar yang baik. Hasil belajar yaitu, perubahan-perubahan yang terjadi pada diri siswa, baik yang menyangkut aspek kognitif, afektif, psikomotor sebagai hasil dari kegiatan belajar (Susanto,2013:5). Berdasarkan hal ini hasil belajar yaitu seperangkat kompetensi pembelajaran yang dikuasai dan harus dicapai siswa menyangkut aspek ranah afektif, ranah kognitif dan ranah psikomotorik setelah mengalami interaksi dalam kegiatan proses pembelajaran melalui proses belajar yang dilakukan oleh siswa.

Hasil belajar yang dicapai siswa tidak terlepas dari faktor-faktor yang mempengaruhi hasil belajar tersebut, secara garis besar faktor yang mempengaruhi hasil belajar dikelompokan menjadi dua bagian yaitu faktor internal dan faktor eksternal. Faktor-faktor yang memberikan kontribusi terhadap proses dan hasil belajar adalah kondisi internal dan eksternal siswa. Kondisi internal mencakup kondisi fisik, seperti kesehatan organ tubuh, kondisi psikis seperti kemampuan intelektual, emosional, dan kondisi sosial, seperti kemampuan bersosialisasi dengan lingkunganya. Kondisi eksternal yang ada di lingkungan siswa, beberapa faktor eksternal seperti variasi dan tingkat kesulitan materi belajar yang dipelajari, tempat belajar, iklim, suasana lingkungan belajar, dan budaya belajar masyarakat akan mempengaruhi kesiapan, proses, dan hasil belajar. Berdasarkan penjelasan diatas faktor internal yang mempengaruhi hasil belajar terletak dalam diri siswa tersebut, sedangkan faktor eksternal yang mempengaruhi hasil belajar siswa yaitu kondisi lingkungan sekitarnya.

Salah satu faktor internal yang mempengaruhi hasil belajar siswa yaitu mengacu kepada konsep diri dari siswa itu sendiri. Konsep diri ini merupakan suatu kepercayaan mengenai keadaan diri sendiri yang relatif sulit diubah. Konsep diri tumbuh dari interaksi seseorang dengan orang-orang lain yang berpengaruh dalam kehidupannya, biasanya orang tua, guru dan teman-teman.

Secara umum, Konsep diri sebagai suatu organisasi dinamis yang didefinisikan sebagai skema kognitif tentang dirinya sendirinya yang mencakup sifat-sifat, nilai-nilai, peristiwa dan memori senmatik tentang dirinya sendiri. Melalui konsep diri siswa dapat bercermin mengenai dirinya sendiri dan merasakan apa yang siswa rasakan dalam merespon segala rangsangan dari luar untuk melakukan dan memahami sesuatu. "Konsep diri adalah pandangan atau persepsi tentang diri sendiri yang bersifat kompleks yang berkaitan dengan karakteristik fisik, sosial, psikologis, nilai dan prinsip dalam hidup" (Budiartawan,dkk,2014:Vol.4). Konsep diri merupakan gabungan dari keyakinan yang dimiliki individu tentang dirinya sendiri yang meliputi karakteristik fisik, psikologis, sosial, emosional, aspirasi dan prestasi. Berdasarkan pemaparan diatas dapat diartikan konsep diri yang dimiliki seseorang yaitu suatu gambaran mengenai dirinya sendiri dan mengenai bagaimana karakteristik fisik dari dirinya sendiri, tentang kejiwaan dirinya sendiri dalam kehidupan sosial, menjaga keseimbangan emosional dirinya sendiri didalam lingkungannya sehari-hari dan mengetahui kemampuan kognitif yang telah dimiliki.

Dilihat dari karakter siswa sekolah dasar pada masa kini siswa lebih cenderung memiliki rasa patah semangat, merasa gagal sebelum mencoba, dari hal tersebut perlu adanya pengembangan dan pembentukan konsep diri yang ditanamkan pada diri siswa sejak dini, pembentukan konsep diri siswa sejak dini perlu adanya bantuan yang menyatakan hal-hal positif mengenai dirinya sendiri seperti motivasi yang positif, penguatan yang positif. Hal ini dapat menghasilkan konsep diri yang lebih psoitif, siswa yang memiliki konsep diri yang positif cenderung tidak memiliki rasa yang pesimis melainkan cenderung memiliki rasa yang optimis dalam dirinya. Konsep diri termasuk salah satu hal yang terpenting untuk mencapai hasil belajar yang baik atau prestasi belajar yang baik.

Berdasarkan faktor Internal yang mempengaruhi hasil belajar tersebut, mata pelajaran yang difokuskan dalam pembahasan ini yaitu IPS (ilmu pengetahuan sosial). Dalam pembelajaran IPS (ilmu pengetahuan sosial) memiliki tujuan yang penting, yaitu mengembangkan pengetahuan, nilai, sikap, keterampilan sosial, fakta, peristiwa, interaksi sosial dalam bermasyarakat, bangsa dan Negara. Didalam 
program sekolah pendidikan, IPS (ilmu pengetahuan sosial) menyediakan kajian terkoordinasi dan sistematis dengan menggambil dari disiplin-disiplin ilmu sosial, seperti antropologi, arkeologi, ekonomi, geografi, sejarah, hukum, ilmu politik, agama, budaya, dan sosiologi. IPS (ilmu pengetahuan sosial) merupakan ilmu yang mempelajari interaksi manusia dengan lingkungan. Hal tersebut sejalan dengan proses pembentukan konsep diri yang dimulai sejak seseorang lahir dan dipengaruhi oleh berbagai faktor yang berkaitan dengan individu. Lingkungan sangat mempengaruhi pembentukan konsep diri seseorang, oleh karena itu terdapat kaitan yang erat antara ilmu pengetahuan sosial dan konsep diri seseorang.

Tujuan utama pembelajaran IPS (ilmu pengetahuan sosial)yaitu "mengembangkan potensi siswa agar peka terhadap masalah sosial yang terjadi di masyarakat, memiliki sikap mental positif terhadap perbaikan segala ketimpangan yang terjadi, dan terampil mengatasi masalah yang terjadi sehari-hari baik yang menimpa dirinya sendiri maupun yang menimpa masyarakat" (Susanto,2013:145).

Berdasarkan hasil observasi yang dilaksanakan, maka ditemukan permasalahan yang ada di sekolah dasar pada umumnya, yaitu konsep diri pada siswa yang belum dikembangkan dan dibentuk secara optimal. Pembentukan konsep diri yang diberikan hanya sebatas penguatan verbal, dan motivasi sederhana yang diberikan oleh guru di sekolah. Sehingga pada masa kini konsep diri yang dimiliki siswa masih lemah, tidak banyak siswa yang memilki konsep diri yang positif, siswa masa kini lebih cenderung malas, pesimis, memiliki rasa takut, dalam melaksanakan pembelajaran di kelas, ini tentunya membuat hasil belajar siswa tidak optimal dalam penguasaan kompetensi. Pada dasarnya setiap siswa memiliki sikap dan karakter tersendiri, tetapi jika guru ataupun orang tua membentuk konsep diri siswa melalui kegiatan yang positif, motivasi dalam kehidupan sehari-hari ataupun motivasi dalam belajar, penguatan yang positif itu sangat membantu pembentukan konsep diri positif pada diri siswa. Dengan adanya konsep diri yang positif dalam diri siswa sangat membantu meningkatkan dan mengoptimalkan hasil belajar siswa dalam penguasaan kompetensi yang diharapkan.

Hal ini dikuat dengan penelitian Dwi Heppy Rochmawati (2014) Berdasarkan penelitian ini bahwa karakteristik responden sebagian besar berumur 19-21 tahun (76\%), pendidikan hampir separuh (44\%) adalah SMP, berdasar tindak kejahatan yang dilakukan terbanyak adalah penganiyaan (36\%), dan lama masa tahanan sebagian besar lebih dari 3 tahun (72\%). Konsep diri terbesar adalah positif yaitu (84\%). Kemampuan memaknai hidup lebih dari separuh adalah tinggi (68\%). Ada hubungan antara konsep diri dengan kemampuan memaknai hidup, artinya semakin tinggi konsep diri maka semakin mampu memberikan makna dalam hidup ditunjukkan dengan nilai pvalue 0,006. Rozan Ismatul Maula Sofwan (2016) Hasil penelitian menunjukkan adanya hubungan positif antara konsep diri dengan komunikasi interpersonal yang efektif antara ibu dan anak. Korelasi antara konsep diri dengan komunikasi interpersonal yang efektif antara ibu dan anak ditunjukkan dengan koefisien korelasi (rxy) sebesar 0,552 ( $\mathrm{p}<0,01)$. Hal ini menunjukkan bahwa hipotesis yang diajukan dapat diterima secara empirik yaitu ada hubungan positif antara konsep diri dengan komunikasi interpersonal yang efektif antara ibu dan anak. Hal tersebut mengandung arti bahwa semakin tinggi konsep diri maka semakin efektif komunikasi interpersonal antara ibu dan anak.

Aslama Puji Astuti (2014) juga menyatakan, Berdasarkan hasil perhitungan yang dilakukan dengan menggunakan teknik analisis korelasi sederhana Product Moment dari Pearson antara konsep diri positif (variabel X) dengan penyesuaian diri (variabel Y) pada mahasiswa FKIP Universitas Lampung angkatan 2014 dari luar Propinsi Lampung artinya (1) Memiliki hubungan yang kuat untuk interval koefisien $r$ 0,600-0,799; (2) Memiliki hubungan yang positif, tanda positif menunjukkan hubungan yang linier searah dan korelasi langsung yang artinya jika konsep diri positif tinggi maka penyesuaian diri juga tinggi, dan jika konsep diri positif rendah maka penyesuaian diri juga rendah; (3) Ditinjau dari sudut indeks diterminasi (r2 x 100\%) diketahui sebesar 44,76\%. Hal ini menunjukkan konsep diri positif (variabel X) memberikan kontribusi terhadap perubahan penyesuaian diri (variabel Y), sedangkan sisanya 55,24\% oleh variabel lain. Wulandari Agustin (2014) korelasi yang diperoleh positif menunjukkan hubungan searah diantara keduanya, sehingga semakin baik konsep diri sendiri yang dimiliki anggota AIESEC LC Bandung, semakin tinggi kefeektifan komunikasi antarpribadi yang dilakukan. Hasil pengujian dengan statistik Z diperoleh nilai Zhitung $(9,418)>$ Ztabel $(1,96)$. Hal tersebut menunjukkan penolakan H0 atau dengan kata lain terdapat hubungan yang signifikan antara variabel konsep diri (X) dengan variabel keefektifan komunikasi antarpribadi (Y). Prabawati Setyo Pambudi, Diyan Yuli Wijayanti (2012) Penelitian yang telah dilakukan diperoleh hasil yaitu karakteristik mahasiswa semester VI PSIK FK UNDIP mayoritas berjenis kelamin perempuan yaitu sebesar 81,5\% (53 mahasiswa), berusia 21 tahun yaitu sebesar 78,5\% (51 mahasiswa), dan mahasiswa kelas reguler lebih banyak dari kelas RIC yaitu yaitu sebesar 75,4\% (49 mahasiswa) dari total 65 mahasiswa. Berdasarkan uji korelasi didapatkan pula hasil 
yaitu ada hubungan antara konsep diri mahasiswa dengan prestasi akademik pada mahasiswa semester VI di PSIK FK UNDIP. Oleh karena itu, institusi pendidikan keperawatan sebaiknya meningkatkan dukungan kepada mahasiswa untuk mencapai konsep diri yang baik. Vebby Diah Ardyanti (2017) Analisis korelasi yang dilakukan pada variable konsep diri dan konformitas menghasilkan nilai signifikansi (p) sebesar $0,465(p<0,05)$ yang mengindikasikan H0 diterima, yaitu tidak adanya hubungan antara konsep diri dengan konformitas pada remaja laki-laki yang mengkonsumsi minuman keras (arak) di Gianyar, Bali. Asep Lukman Efendi (2013) Berdasarkan korelasi antara X1 dan X2 dengan Y adalah 0.566, sehingga sumbangan yang diberikan X1 dan X2 dengan Y adalah 32.10\%. Dapat diambil kesimpulan bahwa konsep diri dalam belajar dan motivasi belajarmahasiswa Bimbingan dan Konseling memberikan sumbangan $32.10 \%$ dalam mempengaruhi prestasi akademik mahasiswa, sedangkan $67.90 \%$ dipengaruhi faktorfaktor lain yang tidak menjadi variabel penelitian ini. Wiji Astutik, Indri Astuti, Abas Yusuf (2014) Berdasarkan uji korelasi "Pearson Correlation" untuk konsep diri dan penyesuain diri didapatkan nilai rhitung= 0,763 dengan nilai signifikansi sebesar $0,00(<0,05)$ hal ini menunjukan terdapat korelasi positif antara konsep diri terhadap penyesuaian diri, yang artinya adalah semakin baik konsep diri siswa, maka semakin baik juga penyesuaian diri siswa.

Berdasarkan uraian yang telah di paparkan, pembentukan dan pengembangan konsep diri secara optimal dapat membantu siswa untuk menunjang hasil belajar yang optimal. Siswa yang memiliki konsep diri yang positif akan lebih mudah mengatasi masalah-masalah dalam proses belajar dan memiliki sikap yang optimis untuk mengikuti pelajaran. Sehingga siswa secara tidak langsung antusias dan lebih mudah menguasai kompetensi pengetahuan. Salah satu nilai penguasaan kompetensi pengetahuan yang perlu dioptimalkan adalah mata pelajaran IPS (ilmu pengetahuan sosial). Penelitian ini dilakukan untuk mengetahui apakah konsep diri memiliki korelasi yang signifikan dengan penguasaan kompetensi pengetahuan IPS, maka akan dilakukan penelitian berjudul "Korelasi Antara Konsep Diri Dengan Penguasaan Kompetensi Pengetahuan IPS Siswa Kelas IV SD Gugus VI Pangeran Diponegoro Denpasar Barat Tahun Pelajaran 2017/2018“.

\section{METODE PENELITIAN}

Penelitian ini merupakan penelitian Ex Post Facto Korelasional karena penelitan ini bertujuan untuk mengetaui koreasi antara konsep diri dengan penguasaan kompetensi IPS, dengan tidak memanipulasi variabel bebas atau menggali fakta yag sudah terjadi sebelumnya. Populasi dalam penelitian ini adalah siswa kelas IV SD Gugus VI Pangeran Diponegoro Denpasar Barat tahun pelajaran 2017/2018 yang berjumlah 401 siswa.

Berdasarkan tabel Issac and Michael, jumlah populasi yan terdapat di Gugus VI Pangeran Diponegoro Denpasar Barat adalah 401 orang siswa dan jumlah sampel yang diambil berdasarkan tingkat kesalahan $5 \%$ berjumlah 186 orang siswa. Pengambilan sampel dalam penelitian ini menggunakan teknik proporsional random sampling yang artirnya teknik pengambilan sampel secara acak dengan memperhatikan jumlah siswa dari masing-masing kelas sesuai dengan proporsi yang terdapat didalam populasi tersebut.

Metode yang digunakan dalam pengumpulan data adalah metode teknik non tes, jens tekik non tes yang digunakan dalam penelitian ini yaitu kuesioner dan pencatatan dokumen. Dalam penelitian ini sesuai dengan data yang dikumpulkan, instrumen yang digunakan adalah kuesioner konsep diri, dan data tentang penguasaan kompetensi pengetahuan IPS siswa kelas IV SD Gugus VI Pangeran Diponegoro Denpasar Barat tahun pelajaran 2017/2018 diperoleh dari pencatatan dokumen.

Kuesioner konsep diri dibuat sendiri berdasarkan teori Syamsul (2010:123) yang digunakan sebagai pedoman indikator yang terdiri dari aspek konsep diri akademis, konsep diri sosial, konsep diri penampilan diri, konsep diri jasmaniah dan konsep diri spiritual. Kuesionner konsep diri sebagai alat ukur untuk mengetaui sejauh mana konsep diri yang dimiliki siswa kelas IV SD Gugus VI Pangeran Diponegoro Denpasar Barat tahun pelajaran 2017/2018. Jumlah item kuesioner yaitu 25 butir pernyataan Pengujian instrumen dalam penelitian ini menggunakan validitas isi dan validitas konstrak. Kuesioer yang digunakan dalam mengukur konsep diri ini menggunakan kuesioner skala likert.

Pencatatan dokumen yang digunakan untuk pengumpulan data penguasaan kompetensi pengetahuan IPS siswa kelas IV SD Gugus VI Pangeran Diponegoro Denpasar Barat tahun pelajaran 2017/2018 dieroleh dari nilai UAS semester I.

Analisis dalam penelitian ini menggunakan analisis statistik inferensial. Teknik analisis data yang digunakan teknik korelasi produc moment yang digunakan unuk mencari hubungan dua variabel yaitu 
variabbel beas dan variabel terikat dengan menggunakan data interval atau ratio. Untuk memenuhi persyaratan uji hipotesis maka diperlukan uji persyaratan analisis yaitu uji normalitas dan uji hipotesis statistik.

Uji normalitas digunakan untuk menguji apakah data variabel bebas dan variabel terikat berdistribusi normal atau tidak, dengan cara menggunakan rumus chi-kuadrat dengan kriteria yang digunakan adalah dengan membandingkan nilai X2tabel dengan X2 hitung pada taraf signifikan 5\% dengan ketentuan X2 hitung < X2tabel maka data berdistribusi normal.

Uji hipotesis statistik menggunakan korelasi produc moment dengan mengetes antara variabel bebas (X) dan variabel terikat (Y). Hipotesis yang diuji dalam penelitian ini adalah Ho yang berbunyi tidak terdapat korelasi yang signifikan antara konsep diri dengan penguasaan kompetensi pengetahuan IPS siswa kelas IV SD Gugus VI Pangeran Diponegoro Denpasar Barat tahun pelajaran 2017/2018, dengan kriteria Kriteria yang digunakan dalam pengujian korelasi product moment ini yaitu dengan menggunakan taraf signifikan 5\%. Adapun ketentuan yang diuji dalam penelitian ini jika rxy hitung > rxy tabel maka H0 ditolak berarti ada korelasi antara konsep diri (X) dengan penguasaan kompetensi pengetahuan IPS (Y) sebaliknya jika rxy hitung < rxy tabel maka H0 diterima berarti tidak ada korelasi antara konsep diri (X) dengan penguasaan kompetensi pengetahuan IPS (Y).

\section{ANALISIS DAN PEMBAHASAN}

Data mengenai konsep diri siswa kelas IV SD Gugus VI Pangeran Diponegoro Denpasar Barat diperoleh melalui penyebaran kuesioner. Sampel yang dibagikan kuesioner berjumlah 186 responden dan diberikan 25 butir pernyataan. Data nilai kuesioner konsep diri dapat dilihat sebagai beirkut:

Tabel 1. Data Nilai Kuesioner Konsep Diri Siswa Kelas IV SD Gugus VI Pangeran Diponegoro Tahun pelajaran $2017 / 2018$

\begin{tabular}{cc}
\hline Data Statistik & Nilai \\
\hline Mean & 78.90 \\
Median & 78 \\
Modus & 74 \\
Skor Maksimum & 98 \\
Skor Minimum & 61 \\
\hline
\end{tabular}

Berdasarkan data nilai kuesioner konsep diri rata-rata siswa kelas IV SD Gugus VI Pangeran Diponegoro Tahun Pelajaran 2017/2018 mendapatkan nilai 78,90. Nilai konsep diri siswa yang tertinggi 98 dan yang terendah 61.

Dari data di atas dapat juga dilihat dalam bentuk grafik, sehingga dapat dilihat sebagai berikut :

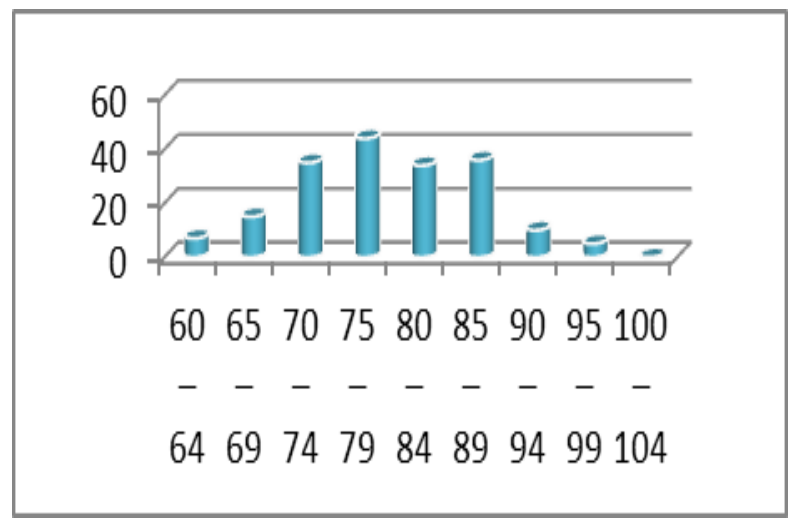

Gambar 1. Histogram Data Konsep Diri

Berdasarkan diagram tentang data konsep diri dapat diketahui bahwa frekuensi nilai terbanyak terdapat pada kelas interval ke-4, selanjutnya dapat dilihat data berikut ini tentang tingkat kategori 
konsep diri siswa kelas IV SD Gugus VI Pangeran Diponegoro Denpasar Barat Tahun Pelajaran $2017 / 2018$.

Tabel 2. Pedoman Konversi PAP Skala Lima Konsep diri

Persentase Konsep Diri

$$
\begin{gathered}
90-100 \\
80-89 \\
65-79 \\
55-64 \\
0-54
\end{gathered}
$$

Kriteria Konsep Diri

Sangat Tinggi
Tinggi
Sedang
Rendah
Sangat Rendah

(Sumber:Agung,2014)

Berdasarkan kategori konsep diri diatas serta hasil analisis data, bahwa rerata dari konsep diri siwa kelas IV Gugus VI Pangeran Diponegoro Denpasar Barat adalah 78,90. Berdasarkan data tersebut maka dapat disimpulkan bahwa nilai konsep diri siswa kelas IV SD Gugus VI Pangeran Diponegoro Denpasar Barat, tergolong kategori sedang.

\section{Deskripsi Data Penguasaan Kompetensi Pengetahuan IPS}

Data tentang penguasaan kompetensi pengetahuan IPS diperoleh melalui pencatatan dokumen, dokumen tersebut adalah daftar nilai ulangan akhir semester 1. Pencatatan dokumen dilakukan sesuai dengan jumlah sampel yaitu 186 orang siswa kelas IV SD Gugus VI Pangeran Diponegoro Denpasar Barat Tahun Pelajaran 2017/2018. Data nilai penguasaan kompetensi pengetahuan IPS dapat dilihat sebagai berikut:

Tabel 3. Deskripsi Data Nilai Penguasaan Kompetensi Pengetahuan IPS Siswa

\begin{tabular}{cc}
\hline Data Statistik & Nilai \\
\hline Mean & 78.88 \\
Median & 79 \\
Modus & 77 \\
Skor Maksimum & 94 \\
Skor Minimum & 66 \\
\hline
\end{tabular}

Berdasarkan data nilai penguasaan kompetensi pengetahuan IPS rata-rata siswa kelas IV SD Gugus VI Pangeran Diponegoro Tahun Pelajaran 2017/2018 mendapatkan nilai 78,88. Nilai Penguasaan Kompetensi Pengetahuan IPS siswa yang tertinggi 94 dan yang terendah 66.

Dari data di atas dapat juga dilihat dalam bentuk grafik, sehingga dapat dilihat sebagai berikut:

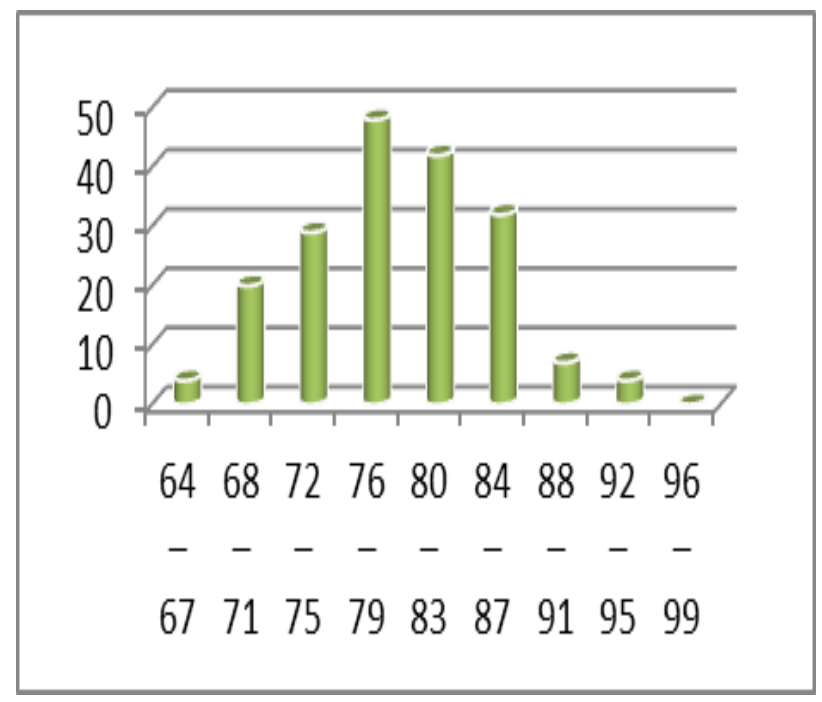

Gambar 2. Histogram Data Penguasaan Kompetensi Pengetahuan IPS 
Berdasarkan diagram tentang data Penguasaan Kompetensi Pengetahuan IPS dapat diketahui bahwa frekuensi nilai terbanyak terdapat pada kelas interval ke-4, selanjutnya dapat dilihat data berikut ini tentang tingkat kategori konsep diri siswa kelas IV SD Gugus VI Pangeran Diponegoro Denpasar Barat Tahun Pelajaran 2017/2018.

Tabel 4. Pedoman Konversi PAP Skala Lima Penguasaan Kompetensi Pengetahuan IPS

\begin{tabular}{cc}
\hline $\begin{array}{c}\text { Persentase Penguasaan Kompetensi Pengetahuan } \\
\text { IPS }\end{array}$ & $\begin{array}{c}\text { Kriteria Penguasaan Kompetensi } \\
\text { Pengetahuan IPS }\end{array}$ \\
\hline $90-100$ & Sangat Baik \\
$80-89$ & Baik \\
$65-79$ & Cukup \\
$55-64$ & Kurang \\
$0-54$ & Sangat Kurang \\
\hline
\end{tabular}

(Sumber:Agung,2014)

Berdasarkan kategori penguasaan kompetensi pengetahuan IPS di atas serta hasil dari analisis data, bahwa rerata dari penguasaan kompetensi pengetahuan IPS siwa kelas IV Gugus VI Pangeran Diponegoro Denpasar Barat adalah 78.88. Berdasarkan data tersebut maka dapat disimpulkan bahwa nilai penguasaan kompetensi pengetahuan IPS siswa kelas IV SD Gugus VI Pangeran Diponegoro Denpasar Barat, tergolong kategori cukup.

Uji normalitas konsep diri (X) dan penguasaan kompetensi pengetahuan IPS (Y) menggunakan teknik uji Chi-Kuadrat $\left(\mathrm{x}^{2}\right)$. Nilai dari variabel $\mathrm{X}$ dan $\mathrm{Y}$ dapat dikatakan berdistribusi normal apabila $\mathrm{x}^{2}$ hitung $<\mathrm{x}^{2}$ tabel.. Hasil uji normalitas konsep diri $(\mathrm{X})$ yaitu $\mathrm{x}^{2}$ hitung $=7,16$. Berdasarkan analisis maka diperoleh $\mathrm{x}^{2}$ hitung $=7,16$ dan menggunakan taraf signifikansi 5\% dengan menggunakan derajat kebebasan 5 , maka diperoleh $x^{2}$ tabel $=11,07$. Hal ini berati $x^{2}$ hitung 7,16 $<x^{2}$ tabel 11,07 maka dapat dinyatakan sebaran data berdistribusi normal. Sedangkan hasil uji normalitas penguasaan kompetensi pengetahuan IPS (Y) yaitu $\mathrm{x}^{2}$ hitung $=2,12$. Berdasarkan analisis maka diperoleh $\mathrm{x}^{2}$ hitung $=2,12$ dan menggunakan taraf signifikansi $5 \%$ dengan menggunakan derajat kebebasan 5, maka diperoleh $x^{2}$ tabel $=11,07$. Hal ini berati $x^{2}$ hitung $2,12<$ $\mathrm{x}^{2}$ tabel 11,07 maka dapat dinyatakan sebaran data berdistribusi normal. Hasil tersebut membuktikan bahwa data kedua variabel bebas dan terikat bersifat normal.

Setelah dilakukan uji prasyarat dan diketahui data berdistribusi normal, dilanjutkan uji hipotesis guna mengetahui adanya korelasi antar variabel. Uji hipotesis yang dilakukan adalah uji hipotesis dengan menggunakan teknik analisis product moment (variabel $\mathrm{X}$ dengan variabel $\mathrm{Y}$ ), maka untuk tujuan analisis data dirumuskan dalam hipotesis nol $\left(\mathrm{H}_{0}\right)$. Hipotesis yang dirumuskan yaitu $\mathrm{H}_{0}$ : Tidak terdapat korelasi yang signifkan antara konsep diri dengan penguasaan kompetensi pengetahuan IPS siswa kelas IV SD Gugus VI Pangeran Diponegoro Denpasar Barat Tahun Pelajaran 2017/2018.

Berdasarkan tabel penolong untuk mencari nilai $r$ dengan menggunakan rumus produc moment dan dibantu menggunakan Microsoft excel 2010. Pengujian koefisien korelasi dengan rumus product moment

diperoleh hasil $r_{x y}=0,265$. Untuk uji koefisien korelasi, digunakan nilai tabel product moment (r) untuk $\mathrm{n}=186$, pada taraf signifikansi $5 \%$ diperoleh hasil adalah 0,148 . Maka dapat dinyatakan $r_{\text {hitung }}>r_{\text {tabel. }}$ Ini berati nilai $r_{\text {hitung }}$ signifikan dengan nilai 0,265 , sehingga $\mathrm{H}_{0}$ yang berbunyi tidak terdapat korelasi yang signifikan antara konsep diri dengan penguasaan kompetensi pengetahuan IPS kelas IV SD Gugus VI Pangeran Diponegoro Denpasar Barat Tahun Pelajaran 2017/2018 ditolak dan $\mathrm{H}_{\mathrm{a}}$ diterima. Berdasarkan hasil perhitungan $r_{\text {hitung }}$ dengan membandingkan $r_{\text {tabel }}$ dilihat dari hasilnya hal ini menunjukan bahwa terjadi korelasi, antara konsep diri dengan penguasaan kompetensi pengetahuan IPS. Sedangkan arah korelasi, dari hasil penelitian ini yaitu arah korelasi positif berarti semakin tinggi konsep diri yang dimiliki siswa semakin meningkat penguasaan kompetensi pengetahuan IPS.

Berdasarkan hasil penelitian yang telah dilakukan mengenai korelasi antara konsep diri degan penguasaan kompetensi pengetahuan IPS siswa kelas IV SD Gugus VI Pangeran Diponegoro tahun pelajaran 2017/2018, uraian yang telah dipaparkan dapat dikemukakan interprestasi, maka hal ini membuktikan bahwa rata-rata siswa kelas IV SD di Gugus VI Pangeran Diponegoro tergolong memiliki konsep diri dengan kategori sedang dan memperoleh nilai pengetahuan IPS dengan kategori cukup, hal ini berarti jika siswa memiliki konsep diri tinggi maka tinggi pula nilai pengetahuan IPS yang diperoleh siswa. Berdasarkan hal tersebut, konsep diri yang dimiliki siswa dalam belajar termasuk dalam konsep diri positif. Konsep diri positif akan mempengaruhi siswa dalam menghadapi kesulitan belajar terutama 
dalam pembelajaran IPS. Konsep diri yang positif akan mempengaruhi nilai penguasaan kompetensi pengetahuan IPS siswa, konsep diri positif memiliki dampak baik dalam proses belajar siswa dan hasil belajar di sekolah ini dikarenakan siswa yang memiliki konsep diri yang positif cenderung memiliki sikap optimis. Hal ini diungkapkan juga menurut Pranata (2014:Vol.2) "individu yang mempunyai konsep diri yang positif meyakini dan memandang bahwa dirinya mampu, individu ini cenderung bersikap optimis terhadap hidupnya dan ini berdampak baik terhadap proses belajar disekolah".

Faktor internal yang mempengaruhi keberhasilan siswa dalam menguasai kompetensi pengetahuan IPS salah satunya yaitu memiliki konsep diri yang positif. Konsep diri siswa yang bermacam-macam dan berbeda antara siswa satu dan siswa yang lain yang akan nantinya memberikan hasil nilai penguasaan kompetensi pengetahuan IPS yang berbeda pula. Apabila seorang siswa mempunyai konsep diri yang positif akan lebih mudah menerima setiap pembelajaran terutama mata pelajaran IPS yang disampaikan oleh guru, siswa tersebut akan lebih cenderung memiliki rasa optimis dalam kegiatan proses belajar dan antusias dalam mengikuti proses pembelajaran di kelas sehingga hasil penguasaan kompetensi pengetahuan IPS dapat optimal, tetapi apabila seorang siswa mempunyai konsep diri negatif akan lebih sulit untuk menerima pelajaran yang telah disampaikan oleh guru.

Konsep diri tumbuh atau terbentuk tidak secara langsung melainkan melalui suatu proses interaksi , motivasi positif yang ada dilingkungan sekitar siswa yaitu lingkungan keluarga, masyarakat, sekolah. Seseorang yang berpengaruh terhadap pementukan konsep diri dalam kehidupan siswa yaitu orang tua, guru, dan teman-teman. Lingkungan sekolah merupakan salah satu proses pembentukan konsep diri pada siswa. Karena guru akan menanamkan hal-hal yag positif dalam diri siswa baik itu motivasi positif, atau arahan-arahan prilaku yang positif. Dengan demikian konsep diri yang positif terbentuk dan berkembang melalui proses belajar di dalam interaksi seseorang dengan lingkungannya.

Dalam penelitian ini untuk uji koefisien korelasi, digunakan nilai tabel product moment (r) untuk $\mathrm{n}=186$, pada taraf signifikansi $5 \%$ diperoleh hasil adalah 0,148 . Maka dapat dinyatakan $r_{\text {hitung }}>r_{\text {tabel. }}$. Ini berati nilai $r_{\text {hitung }}$ signifikan dengan nilai 0,265 , sehingga $\mathrm{H}_{0}$ yang berbunyi tidak terdapat korelasi yang signifikan antara konsep diri dengan penguasaan kompetensi pengetahuan IPS kelas IV SD Gugus VI Pangeran Diponegoro Denpasar Barat Tahun Pelajaran 2017/2018 ditolak dan $\mathrm{H}_{\mathrm{a}}$ diterima. Hal ini sejalan dengan penelitian yang dilakukan oleh Pranata (2014), dengan nilai $r_{\text {hitung }}=0,78$ yang mempunyai arti bahwa semakin tinggi hasil belajar matematika yang disebabkan oleh bimbingan belajar orang tua dan konsep diri memberi sumbangan sebesar 60,88\%.

\section{KESIMPULAN}

Hasil analisis menunjukan bahwa terdapat korelasi yang signifikan antara konsep diri dengan penguasaan kompetensi pengetahuan IPS siswa kelas IV SD Gugus VI Pangeran Diponegoro Denpasar Barat Tahun Pelajaran 2017/2018. Katagori korelasi yang diperoleh termasuk korelasi yang lemah antara konsep diri dengan penguasaan kompetensi pengetahuan IPS. Sedangkan arah korelasi adalah positif karena nilai $r$ positif, berati semakin tinggi konsep diri semakin meningkatnya penguasaan kompetensi pengetauan IPS.

Berdasarkan hasil analisis dengan menggunakan rumus product moment melalui Microsoft excel 2010 dan menghitung manual. Nilai tabel product moment $(r)$ untuk $n=186$, pada taraf signifikansi $5 \%$ diperoleh hasil adalah 0,148. Maka dapat dinyatakan rhitung >rtabel. Ini berati nilai rhitung signifikan dengan nilai 0,265 , sehingga $\mathrm{H} 0$ yang berbunyi tidak terdapat korelasi yang signifikan antara konsep diri dengan penguasaan kompetensi pengetahuan IPS kelas IV SD Gugus VI Pangeran Diponegoro Denpasar Barat Tahun Pelajaran 2017/2018 ditolak dan Ha diterima.

Berdasarkan uraian tersebut kita mengemukakan interprestasi, maka hal ini berati bahwa rata-rata siswa yang tergolong memiliki konsep diri dengan kategori sedang dan memperoleh nilai penguasaan kompetensi pengetahuan IPS yang cukup, dibandingkan siswa yang memiliki konsep diri dengan kategori yang tinggi tentu mendapatkan nilai penguasaan kompetensi pengetahuan IPS tinggi pula. Jadi dapat disimpulkan bahwa terdapat korelasi yang signifikan antara konsep diri dengan penguasaan kompetensi pengetahuan IPS siswa kelas IV SD Gugus VI Pangeran Diponegoro Tahun Pelajaran 2017/2018 dengan memiliki arah korelasi positif.

Adapun saran yang dapat disampaikan berdasarkan hasil penelitian ini adalah (1) Kepada guru, berdasarkan temuan penelitian yang diperoleh, kepada guru disarankan agar lebih menumbuhkan dan membentuk kosep diri pada siswa sejak dini agar membbantu siswa dalam proses belajar dikelas sehingga tujuan pembelajaran tercapai secara optimal. (2) kepada sekolah, berdasarkan temuan penelitian, kepada kepala sekolah disarankan agar dapat menggunakan hasil penelitian ini sebagai pendukung sumber belajar guru dalam meningkatkan kualitas pembelajaran dengan membentuk dan menumbuhkan konsep diri positif siswa dalam belajar di sekolah sehingga sekolah mampu menghasilkan 
siswa yang berkualitas. (3) kepada peneliti lain, Berdasarkan temuan penelitian, kepada peneliti disarankan agar hasil penelitian ini digunakan sebagai referensi untuk melaksanakan penelitian selanjutnya dan semoga penelitian ini bermanfaat bagi seluruh masyarakat yang menggunakan penelitian ini

\section{DAFTAR PUSTAKA}

Agung, Gede. 2014. Metodelogi Penelitian Pendidikan. Malang: Aditya Media Publising.

Asep Lukman Efendi. 2013. Hubungan Antara Konsep Diri dalam Belajar dan Motivasi Belajar dengan Prestasi Akademik Mahasiswa. Jurnal Bimbingan dan Konseling FKIP Universitas Lampung. Vol 1 nomor 1 .

Aslama Puji Astuti. 2014. Hubungan Konsep Diri Positif dengan Penyesuaian diri Mahasiswa FKIP Unila Luar Lampung. ALIBKIN (Jurnal Bimbingan Konseling) Unila. Vol 3, No 4.

Bachri Thalib, Syamsul. 2010. Psikologi Pendidikan Berbasis Analisis Empiris Aplikatif. Jakarta:Kencana Prenadamedia Group.

Budiartawan, Madri, Rati. 2014. "Hubungan Konsep Diri dan Pola Asuh Orang Tua Terhadap Hasil Belajar IPA Siswa Kelas V SD Di Desa Selat". Jurnal Mimbar PGSD Universitas Pendidikan Ganesha. Volume 2 Nomor 1, di akses tanggal: 27 Desember 2017.

Dwi Heppy Rochmawati. 2014. Hubungan Antara Konsep Diri dan Kemampuan memaknai Hidup pada Narapidana Remaja di Lembaga pemasyarakatan Kelas 1 Semarang. Jurnal Keperawatan Soedirman (The Soedirman Journal of Nursing). Volume 9, No.3.

Permendikbud. 2016. Peraturan Menteri Pendidikan dan Kebudayaan Republik Indonesia Nomor 22 Tahun 2016 Tentang Standar Proses Pendidikan Dasar dan Menengah. Jakarta: Kementerian Pendidikan dan Kebudayaan. di akses tanggal: 22 Oktober 2016.

Prabawati Setyo Pambudi, Diyan Yuli Wijayanti. 2012. Hubungan Konsep Diri dengan Prestasi Akademik pada Mahasiswa Keperawatan. Jurnal Nursing Studies. Volume 1, Nomor 1.

Rokhmatika, L dan Eko darminto. (2013). Hubungan Antara Persepsi Terhadap Dukungan Sosial Teman Sebaya Dan Konsep Diri Dengan Penyesuaian Diri Di Sekolah Pada Siswa Kelas Unggulan. Jurnal Mahasiswa Bimbingan dan Konseling. Vol 01 No 01.

Rozan Ismatul Maula Sofwan. 2016. Hubungan Antara Konsep diri dengan Komunikasi Interpersonal Yang Efektif antara Ibu dan Anak. Jurnal Psikologi Perseptual. Vol 1 No 2.

Susanto, Ahmad. 2014. Teori Belajar dan Pembelajaran Di Sekolah Dasar. Edisi Pertama. Jakarta: Kencana Prenadamedia Group.

Susanto, Ahmad. 2014. Perkembangan Pembelajaran IPS Di Sekolah Dasar. Jakarta: Kencana Prenadamedia Group.

Vebby Diah Ardyanti. 2017. Hubungan Konsep Diri dengan Konformitas pada Remaja Laki-Laki yang Mengkonsumsi Minuman Keras (Arak) Di Gianyar, Bali. Jurnal Psikologi Udayana. Vol 4 No 1

Wiji Astutik, Indri Astuti, Abas Yusuf. 2014. Hubungan Antara Konsep Diri dengan Penyesuaian Diri Siswa Kelas X SMA Islambawari Pontianak. Jurnal Bimbingan dan Konseling FKIP UNTAN Pontianak. Volume 1 nomor 2.

Wulandari Agustin. 2014. Hubungan Antara Konsep Diri dengan Keefektivan Komunikasi Antarpribadi. Jurnal Kajian Komunikasi Unpad, Volume 2, No. 2 